\title{
Activities of Musicians of Kazakhstan in the Years of the Great Patriotic War On the Occasion of the 75th Anniversary
}

\author{
Dana Zh. Zhumabekova ${ }^{1, *}$ \\ ${ }^{1}$ Faculty of Orchestral Performance, Kazakh National University, Nur-Sultan city, Kazakhstan \\ "Corresponding author. Email: danazhumabekova@mail.ru
}

\begin{abstract}
The Great Patriotic War of 1941-1945 was the liberation war of the Soviet people against Nazi Germany and its allies, the most important and decisive part of the Second World War (1939-1945).

The article is devoted to the activities of visiting musicians in Kazakhstan during the Great Patriotic War (1941-1945). They made a great contribution to the formation of the Kazakh violin school. In Alma-Ata, composers S. Prokofiev and G. Popov, S. Tulikov and O. Strok, directors M. Eisenstein and Yu. Zavadsky, artists G. Ulanova, N. Mordvinov, B. Babochkin, N. Kryuchkov, M. Zharov worked with special enthusiasm.
\end{abstract}

In 1944, Alma-Ata State Conservatory was opened and was named after Kurmangazy. Among the musicians evacuated to Alma-Ata during the war years were famous performers and teachers V.S. Hess, C.G. Bruckner, I.B. Kogan, A.A. Pikaisen and others.

Keywords: musical culture, Kazakhstan, violin, composer, teacher, education

\section{INTRODUCTION}

At the present stage, the Republic of Kazakhstan is showing deep interest in its historical past. And this is natural. The country gained independence and became a sovereign state. Such an event cannot but cause, on the one hand, an increase in the growth of national selfawareness, and on the other, stimulate an objective look at the past. As you know, it is impossible to predict the future without knowing one's history, roots, and social experience of previous generations.

There is no need to prove that when Kazakhstan was a part of the USSR, the republic had to work with maximum efficiency for the war fronts. Kazakhstan, as the rear region, has become one of the ways of life, took the evacuees. He also acted as a springboard for immigrants and exiled people.

During the harsh days of the Great Patriotic War, a large group of art workers from various cities of the Soviet Union was evacuated to Alma-Ata, then the capital of Kazakhstan. These were composers and performers, violinists, cellists, pianists, as well as musicologists and theater and film actors. In Alma-Ata, everyone then worked with a special enthusiasm. Composers S. Prokofiev and G. Popov, S. Tulikov and O. Strok, directors M. Eisenstein and Y. Zavadsky, artists G. Ulanova, N. Mordvinov, B. Babochkin, N. Kryuchkov, M. Zharov, violinist Y. Targonsky, cellist G. Pekker, pianists Y. Guz, B. Nakhutin and many others.

While in Kazakhstan in the summer of 1942, S. Prokofiev proceeded to create the opera "Khan Buzai", based on Kazakh musical folklore. By September of this year, three out of five opera paintings were painted. However, unfortunately, the opera remained incomplete.

The creative process in those most difficult years was striking in that it was not only an individual creative action, for example, of a major composer and performer, but also a matter of national importance.

The development of musical culture in Alma-Ata in the most difficult years led to the need to provide the country, first of all, with pedagogical musical personnel, which gave rise to certain beginnings. In those conditions, let us emphasize an almost incredible fact: in 1944 the Alma-Ata State Conservatory was opened and was named Kurmangazy.

As we see, despite the difficulties of the war years ${ }^{1}$, the state found an opportunity to pay attention to the

In the same 1944, the Gnessin State Music and Pedagogical Institute was opened in Moscow. 
construction of new cultural centers. The state action was legalized on July 24, 1944 by the Decree of the Council of People's Commissars of the Kazakh SSR No. 402: "On the organization of a conservatory in the city of Alma-Ata". Prominent figures of Russian culture, who were in Alma-Ata during the evacuation, contributed to the opening of the first music university in the republic. We are talking about G.S. Ulanova, Yu.A. Zavadsky, N.I. Sats and V.P. Maretskaya.

\section{THEORETICAL BACKGROUND TO THE RESEARCH}

In 1945 the rector of the conservatory ${ }^{2}$ became professor A.K. Zhubanov, People's Artist of the Republic, who received the title of Doctor of Art History without defending a thesis. Historically, Akhmet Kuanovich, a major composer of Kazakhstan, had the privilege of becoming one of the founders of professional musical education in the republic.

Among the musicians evacuated to Alma-Ata during the war, there were well-known performers and teachers, for example, V.S. Hess, K.G. Bruckner, I.B. Kogan, A.A. Pikaisen and several others. They turned out to be the creators of violin classes in Kazakhstan.

The names of some of the founders of violin education in Kazakhstan are well known. Among them, for example, Professor V.S. Hess, representative of the violin school in Moscow. Little is known about the others today, with the archives being the only source. Based on the discovered archival materials (mainly in the Central State Archive of the Republic of Kazakhstan, the Central State Archives of the Republic of Kazakhstan), as well as thanks to the testimonies of students, today it became possible to show the versatile activities of such major violin teachers in Kazakhstan as Karl Gustavovich Bruckner and Joseph Benediktovich Kogan.

A special figure in the development of the professional violin school in Kazakhstan was Veniamin Solomonovich Hess (1909-1986), Honored Teacher of the Kazakh SSR, Honored Art Worker of the Kazakh SSR, professor. "He became one of the leading figures in the musical culture of the republic, laying the foundations for the active development of violin performance", is written in the annals of the Kazakh National Conservatory named after, created in the $21 \mathrm{st}$ century [1]

V.S. Hess is a versatile musician: a performer and transcriptor of compositions for violin, a teacher, as his students testify, from God. Like many major

2 The first rector of the Alma-Ata Conservatory named after Kurmangazy is a graduate of the St. Petersburg Conservatory I.V. Kruglykhin (1944-1945). performers, V.S. Hess took part in the correction of the solo parts of new works by composers of Kazakhstan.

Even a dry list of the main circumstances of the violinist's career speaks volumes. Let's list those in which the musician was especially lucky:

- V.S. Hess is a pet of the famous "smithy" P.S Stolyarsky $^{3}$, from where many talents of the Russian violin school came;

- he studied at the Moscow Conservatory in the class of the violinist, professor B.O. Seabor ${ }^{4}$ an outstanding musician, performer and teacher;

- V.S. Hess was lucky that, as a young musician, he goes through the school of orchestral and ensemble performance in Moscow, in the Bolshoi Theater Orchestra and in Persimfans, organized by L.M. Zeitlin;

- pedagogical path of V.S. Hess begins in Moscow (in one of the music schools of the Kuibyshevsky district), and already in 1939 he was invited to the Central Music School at the Moscow Conservatory, which was a great honor and recognition of his professional merits;

- his most active creative years (forty years) V.S. Hess connects with various musical organizations, but, above all, with the Alma-Ata Conservatory, where he was invited.

In 1944, the musician arrives in Kazakhstan by invitation (after demobilization from the cavalry regiment of the Alma-Ata garrison). The republic greeted him hospitably and became his second homeland $^{5}$.

He entered the history of Kazakh musical culture as one of the founders of the national violin school. In 1952, Veniamin Solomonovich Hess became the head

Odessa boarding school. PS Stolyarsky is the first specialized music school in the USSR for gifted children, opened by the violinist-teacher Pyotr Solomonovich Stolyarsky in 1933. Similar educational institutions were later created in Moscow, Leningrad, Sverdlovsk on the model of the Odessa musical ten-year. Pupils of the school P.S. Stolyarsky were Nathan Milstein, Samuel Furer, Boris Goldstein, Elizabeth Gilels, David Oistrakh.

B.O. Sibor (1880-1961) Honored Artist of the RSFSR professor at the Moscow Conservatory. He graduated from the St. Petersburg Conservatory under L. Auer, and then improved his skills under J. Joachim.

In connection with the celebration of the 100th anniversary of the birth of V.S. Hess, who took place in the new capital Astana, one of his students writes: "I was very pleased to know that Kazakhstan has a memory and respect for people of art, one of whom was my teacher Veniamin Solomonovich Hess. He was my teacher for the last 4 years before entering the Moscow Conservatory. Tchaikovsky. Remembering those years, I gratefully note the wonderful violin school that I received while studying with Benjamin Solomonovich. " Elvira Nakipbekova, Honored Artist of the Republic of Kazakhstan. The letter is dated May 10, 2009. 
of the department of stringed instruments (after K.I. Babaev) at the Alma-Ata Conservatory.

The name of Karl Gustavovich Bruckner is known to very few modern musicians. This is unfair because he was a musician of very versatile talent - a performer, violin virtuoso, a brilliant teacher.

In 1941 K.G. Brueckner was evacuated to AlmaAta. For almost two years (from September 1, 1941 to October 5, 1943), the violinist worked as a violin teacher at the Alma-Ata Musical and Choreographic Combine named after I. Tchaikovsky. He was also a soloist of the Theater Orchestra (named after Mossovet).

An erudite musician with extensive experience in solo and orchestral playing, with excellent knowledge of violin methodology, he was an extremely responsive and conscientious teacher.

His student Ermek Serkebaev recalled: "Karl Gustavovich Bryukner did his best to raise the level and qualifications of violin students of the musical and choreographic combine ... In addition, he really liked Kurmangazy's kuis and Abai's melodies. He was inspired by the originality of their composer's work. Karl Gustavovich has repeatedly said that after the war, the national Kazakh culture will say its weighty word in the international artistic arena, and all of Europe will applaud its art" [2]. In many ways, Brueckner turned out to be a visionary.

The musician had a phenomenal memory, he read brilliantly from sight, and he knew some symphonic works and performed them by heart in a piano arrangement. Brueckner was a universal musician, in particular, he owned a piano and played many violin compositions not only on the violin, but also on the grand piano. His knowledge of musical literature has always amazed his students.

K.G. Bruckner actively gave concerts (in the halls of the Kazakh State Philharmonic named after Dzhambul and the Musical and Choreographic Combine). I. Kogan wrote: "One of the largest violinists, Karl Gustavovich Brueckner, is currently working in Alma-Ata ... His playing technique does not know any difficulties and is remarkable in its ease" [3].

His huge repertoire included Beethoven's "Kreutzer's", Tchaikovsky's concert, Saint-Saens's "Havanez", Rimsky-Korsakov's "Bumblebee Flight" (edited by Hartman), F. Chopin's "Nocturne" (edited by Wilhelmy) and much more. "Waltz" No. 6 of Chopin, he played in his own transcription, flashing his wonderful staccato. Due to the sophistication of strokes, his game was distinguished by a variety of shades and colors.

Before the concert, held on June 12, 1943, Yu. A. Zavadsky noted in his opening speech "the amazing virtuosity, lightness and ease, with the help of which the violinist overcame all the dizzying technical difficulties of the program, and also highlighted the scale of the performing concept" [4].

In the class of K.G. Brückner for three years (19411943) studied E. Serkebaev, who at the age of fifteen entered the musical and choreographic combine. The young violinist surprised the selection committee with the performance of several melodies of Kazakh folk songs, which he played by ear. "Imagine the surprise of my teacher when it turned out during the lesson that I did not know a single note, but played by ear. I had to comprehend musical literacy and start searching for my place in art.

Fortunately, there was a sensitive teacher nearby who had brought up more than a dozen good musicians. Many of those with whom I studied then became outstanding figures of Kazakhstan and world art. These are violinist Viktor Pikayzen, conductors Fuat Mansurov and Gaziz Dugashev, Nurgisa Tlendiev and Shamgon Kazhgaliev, composers Gaziza Zhubanova and Yerkegali Rakhmadiev, "recalled the People's Artist of the USSR Ermek Serkebaev [5].

In October 1943 K.G. Brueckner was recalled to Moscow, where he continued his creative activity. What he did during his life in Kazakhstan was a valuable contribution to his musical culture.

\section{CORRELATION STUDY ON PRINCIPLES OF VIOLIN PLAYING}

In September 1942, the family of the Honored Artist of the Republic of Kazakhstan Joseph Benediktovich (Bentsionovich) Kogan (1920-1982) was evacuated to Alma-Ata. The Republic of Kazakhstan has become a second homeland for them. From 1942 to 1954, Kogan worked as a solo violinist at the Dzhambul Kazakh State Philharmonic.

A. Tolganbaev, a violinist's student, emphasized: "I loved, appreciated, respected Joseph Kogan, an excellent musician, experienced teacher, and intelligent person. When a stream of Jewish refugees poured into Israel from Kazakhstan and other republics of the USSR, Joseph said: - No, I will not go anywhere from this land. He lived in Kazakhstan during the difficult years of the Great Patriotic War, worked here, earned honor and respect. This is my Motherland" [6].

In 1954 he completed his academic education, interrupted by the war: he had a phenomenal musical memory, I.B. For two years, Kogan graduated with honors from the Alma-Ata Conservatory in violin. And it is not surprising that in the same year Joseph Benediktovich was invited to the position of a teacher in his Alma mater. A.K. Zhubanov trusted his 
pedagogical abilities and immediately gave his own violin class.

At the department headed by Professor V.S. Hess, K.I. Babaev, V.D. Pankratov, L. Ya. Edelman and I.B. Kogan. The latter was distinguished by the fact that he met many future students long before they entered the conservatory and continued contacts with his pupils after they graduated from the conservatory.

In his class, professor I. Kogan made extensive use of the demonstration method. In his hands, the violin was always in action. The teacher showed a lot, especially technical moments - he characterized the ways of performing certain strokes, suggested his own fingering.

It is well known that the technical apparatus of the violinist is created on scales and etudes. "Turning to the question of special work on artistic and technical elements, do not forget that they should be carried out with careful auditory self-control and relentless attention to the quality of the episodes being studied" [7], Joseph Benediktovich instructed in his works.

In the textbooks published by I. Kogan, such as "Caprices for Solo Violin" (1970), "24 Etudes for Violin" (1978), the basis was the material of Kazakh folk cues and songs. To this day, his caprices and sketches are widely used in the teaching and pedagogical practice of music schools and colleges. The violinist ingeniously invented his own line or fingering variants: for example, for Etude No. 22 he offered 30 variants of performance.

Articles and other literary works of I. Kogan are of scientific interest in the field of the history of performance. Among them: about the first professional Kazakh violinists - R. Shanin, K. Musin, B. Kozhamkulova. In the brochure "Methodical and Performing Analysis of Violin Works by Composers of Kazakhstan" (1982) I. Kogan examines in detail concert pieces by Kazakh composers such as "Aria" by A. Zhubanov, "Kui on the theme" Jez - Kiik "," Poem "and" Reflection "M. Tulebaeva," Melody "by V. Velikanov.

I. Kogan was also involved in the processing of Kazakh folk melodies and cues: Kurmangazy and Tattimbet, Dauletkerei and Bayserke. The most finished and organic here were kyu "Kenes" ("Council") for violin and piano or transcription of Abai's song for violin and piano ensemble "Aittym Salem, Kalamkas" ("Hello to you, Kalamkas").

The performing skills of I. Kogan had a noticeable impact on the composer work of Kazakhstan. This became especially evident in the communication of composers with a violinist during the creation of works. The result often was a dedication inscription. I. Sogatov dedicated the Concert for violin and orchestra to I.
Kogan (1967), E. Brusilovsky Sonata for solo violin (1969). Joseph Benediktovich also became the first performer of violin and orchestra concerts by B. Amanzholov and B. Bayakhunov ${ }^{6}$.

\section{EXECUTIVE ART OF YOUNG ARRIVING MUSICIANS}

Information about the work of A.A. Pikaisen are not yet sufficient and require further investigation. We only inform you that Alexander Abramovich Pikayzen, (professor at the Kiev Conservatory, Honored Artist of the Ukrainian SSR), along with his son Viktor Pikayzen, a student of D.F. Oistrakh, People's Artist of the USSR, was among those evacuated from Kiev. In 1941-1944, he taught not only the violin class at the Music and Choreography Plant ${ }^{7}$, but also conducted the student symphony orchestra. In military Alma-Ata, a talented young violinist first studied with his father at the Musical-Choreographic Combine.

During the war years, in 1943, the national repertoire for violin was also replenished. The Poem for violin and orchestra was written by Mukan Tulebaev ${ }^{8}$. It was conceived as the second part of the Violin Concerto. But the composer did not have to implement this idea.

V. Pikaisen was lucky: at the age of nine he first performed the iconic work for Kazakhstan "Poem" for violin and piano fis moll by M. Tulebaev, and his father Alexander Abramovich performed this piece with an orchestra conducted by I. Piradov at the Decade of Literature and Art of the Republics Central Asia and Kazakhstan in 1944 in Tashkent. In this regard, N. Ketegenova erroneously indicates that "the violinist V. Pikaisen was the soloist" [8].

The work of People's Artist of the USSR M. Tulebaev aroused rave reviews from the public and music critics. Time has shown that the "Poem" for violin and orchestra by $\mathrm{M}$. Tulebaev has taken a strong place in the treasury of the national treasure of Kazakh music.

People's Artist of the USSR V. Pikaisen recalls: "During the war years, a lot of outstanding masters of culture were evacuated to Alma-Ata. At that time, the Mossovet Theater was working, the great ballerina G.

\footnotetext{
6 B. Bayakhunov's concert was written in 1960 as a thesis. I was first performed on May 20,1960 at a graduation concert in the Chamber Hall of the Alma-Ata Conservatory.

During the war years in Alma-Ata, in order to save money, three educational institutions were united: a music school, a children's music school and a choreographic school, transforming them into a music and choreographic combine.

The first performer of the "Poem" by M. Tulebaev was the local violinist Joseph Kogan at the Dzhambul Philharmonic in 1943. The composer began the orchestration of "Poems" in the spring of
} 1944. 
Ulanova danced at performances at the Abai State Academic Opera and Ballet Theater almost twice a week. It seemed that the air in the city was saturated with art. We have always felt a very warm, cordial attitude of the people around us.

I performed G. Wieniawski's Second Violin Concerto at the age of nine, accompanied by the State Symphony Orchestra conducted by N. Rakhlin, who was on tour at that time. The Concert of Mendelssohn in my interpretation was often played on Kazakh radio, I learned the Concert of Tchaikovsky and "Faust" by Veniavsky, and all this, being a student of the Musical and Theater College.

The violin class was then taught by I.A. Lesman, E.P. Antopolsky, including my father, who at the same time worked as accompanist of the orchestra of the State Academic Opera and Ballet Theater named after I. Abay. The now famous singer, People's Artist of the USSR Yermek Serkebaev began to study with him on the violin. I remember he played Handel's Sonatas for Violin and Piano. We were in Alma-Ata from 1941 to 1944 and my family still has the warmest memories of Kazakhstan".

\section{CONCLUSION}

So, we have shown how cultural figures from different regions of the former USSR turned out to be not witnesses, but direct participants in the formation of the Kazakh violin school. Many of them during the Great Patriotic War, as well as in the first post-war decades, were evacuated to Kazakhstan and, despite everyday difficulties, and sometimes political pressure, musicians, including violinists, continued to study and teach. In a word, they brought real professional help to the republic, which hospitably opened the doors of its schools and colleges, the conservatory and the philharmonic society for them.

\section{References}

[1] Kazakh National Conservatory. Kurmangazy // Ed. J. Ya. Aubakirova. Almaty, 2004.S. 166-175

[2] TsGA RK, F. 1543. Op. 1.D. 54.L. 103. Kogan I.B. Violin art in Alma-Ata (1930-1945). P.94

[3] In the same place. P. 94

[4] In the same place. P. 95 Introductory speech by Yu.A. Zavadsky.

[5] A. Kalieva Great vocalist. // Kazakhstan truth. November 19, 2013. S.10.

[6] A. Tolganbaev. Confession of a cruel fate. Almaty, 1993.S. 84

[7] I.B. KoganB. Works by the composers of Kazakhstan for violin.-Alma-Ata, 1982. P. 10

[8] Mukan Tulebaev: Album-book (to the 100th anniversary of his birth). Comp. N. Ketegenova. Almaty, 2013. P. 42 